\title{
Technical and environmental characterisation of recycled aggregate for reuse in bricks
}

\author{
Sabrina Sorlini ${ }^{1,{ }^{*}, \text { Luca }}$ Rondi $^{1}$, Nicola Bettini ${ }^{1}$, Carlo Collivignarelli ${ }^{1}$, Giovanni Plizzari ${ }^{1}$ \\ ${ }^{a}$ Department of Civil Engineering, Architecture, Land, Environment and of Mathematics, University \\ of Brescia, Via Branze 43, Brescia, 25123, Italy
}

\begin{abstract}
Waste mud coming from an aggregate washing plant was formerly used as filling material for a pond, aimed at the recovery of an abandoned quarry. Once completed the filling capacity of the pond, the need for identifying a possible reuse of mud produced by the plant arose in order to avoid landfill disposal. Therefore, mud has been geometrically, physically and chemically characterised for its recovery as construction material. A variety of tests was carried out on mud samples as required by EN technical specifications and by Italian environmental standards, focusing particularly on leaching behaviour. The tested material showed satisfactory physical and chemical properties and a release of pollutants below the limits set by the Italian code. Many mix-designs for the production of unfired bricks made of waste mud, sand and straw, stabilised and non-stabilised with lime, gypsum or cement, were developed. The bricks were tested in order to evaluate mechanical properties and leaching behaviour. Mud bricks provided remarkable compressive strength, even if not suitable for structural elements. The use as interior design to minimise humidity changes and to facilitate a thermal insulation is fostered, thus strengthening the so-called green building economy.
\end{abstract}

\section{Introduction}

The construction industry is a main issue for environmental sustainability because it produces large amounts of carbon dioxide, exploits natural resources and produces but rarely reuses/recovers wastes. A growing spread of the green building economy appears to be the only solution able to ensure sustainable development. Although in recent years the green building economy and the popular environmental awareness were mainly focused on energy, material (i.e. natural resources) saving and waste recycling have probably the most significance for green economic transformation. Following this idea, it will be possible to decrease quarrying activities (considering that natural aggregates are not a renewable resource) and amount of wastes to dispose of in landfills, thus avoiding environment degradation and pollution. For instance, in Italy, quarrying activities still represent the main source for aggregate supply in the construction sector, with an amount of natural resources extracted that was stated at about 120 million $\mathrm{m} 3$ in 2012 [1]. In the late years, industrial

\footnotetext{
${ }^{*}$ Corresponding author. sabrina.sorlini@unibs.it
} 
waste management became an increasing problem, due to the restrictions in landfill disposal prescribed by international regulations. Therefore, waste recovery is considered as an increasingly necessary option, especially the reuse as recycled aggregate in construction can reduce the exploitation of natural quarries. Several types of waste can be recovered in this field, like steel slags, municipal solid waste incineration (MSWI) slags, construction and demolition $(C \& D)$ waste, mud from natural aggregate washing etc. Italian regulation on waste recovery allows the use of these materials both directly in the environment (road and railway basements, excavation filling etc.), and indirectly, through the production of concrete and bitumen $[2,3]$.

Several experimental researches investigated the opportunity to use waste mud or dredged sediments specifically for the production of bricks $[4,5,6,7]$. Other investigations of mud properties covered the recovery as material for geopolymers production, as containment barrier or protection of groundwater and as wastewater treatment material [8, $9,10]$.

This study aims at investigating the possible recovery of waste mud obtained from an aggregate washing plant as unfired bricks. An extensive experimental campaign was carried out in order to determine geometrical, physical and chemical characteristics of mud, according to [11]. Leaching behaviour was also carefully investigated. Bricks produced using only mud and fibre/lightening or stabilised with lime, gypsum or cement were designed and tested in order to determine mechanical properties and to verify the environmental suitability.

\section{Experimental program}

\subsection{Recycled mud}

The material employed in this research was mud obtained from an aggregate washing plant located in northern Italy (Bergamo, Italy). The plant treats, by means of crushing and sieving systems, inert material coming from quarries, construction and demolition waste and excavation of construction sites. The product obtained from this plant is an aggregate used in the construction sector (Fig. 1).

In order to optimize the aggregate granular separation, the raw materials are regularly washed with water in the sieving devices. The residue resulting from washing operations consists of wet fine aggregates, which is about $2-10 \%(\mathrm{w} / \mathrm{w})$ with respect to the raw material treated in the plant. This mixture of fine aggregate and water is then treated by means of a sedimentation and a filter press system. In the settler, an anionic polyelectrolyte DRYFLOC PCP 1® based on polyacrylamide, soluble in water and insoluble in solvents, is added in order to facilitate the liquid-solid separation. The final fine aggregate (named "recycled mud") is mainly composed of silt, and in slight percentages of sand and clay.

Originally the mud was used as filling material for a pond, aimed at the recovery of an abandoned quarry. This study was aimed at researching an alternative solution for mud reuse in the construction sector in order to avoid landfill disposal.

A comprehensive characterisation was carried out on different waste mud samples, hereinafter named "S1", "S2", "S3", and "S4". 


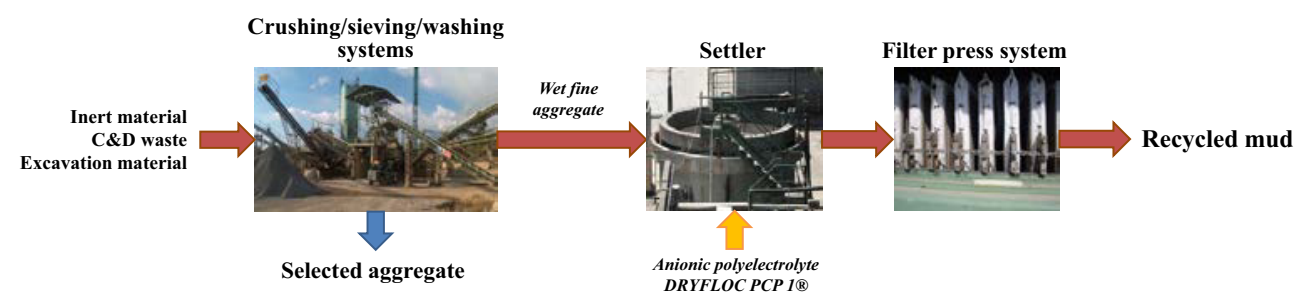

Fig. 1. Scheme of the aggregate washing plant producing the mud investigated in this research.

\subsection{Recycled mud characterisation}

Technical properties of mud samples (geometrical, physical and chemical) were determined in accordance with the UNI Norm for "Aggregates for mortar" [11] and its Italian accomplishment [12]. The latter provides, for several requirements, limit values in accordance with the different final destinations. The environmental characterisation of mud (chemical composition and leaching behaviour) was carried out in accordance with the Italian Norm [2], which rules over the waste characterisation, reuse and recovery, and the Italian Ministerial Decree that is the specific reference for the leaching test [3].

\subsubsection{Geometrical and physical properties}

The geometrical properties investigated in this study were the particle size distribution and the quality of fines. The granulometric composition was determined through the testing method [13] specifically addressed to aggregates characterised by particles with grain size lower than $75 \mu \mathrm{m}$. The quality of fine particles was carried out by means of two tests: sand equivalent and methylene blue value.

Regarding physical properties, the Atterberg limits were firstly determined for the assessment of mud plasticity behaviour, since materials mainly composed by fine particles (as silt and clay) are strongly influenced by the interaction between grains (and their mineralogical composition) and water. Particle density and water content tests were also carried out in order to acquire important values for the optimal design of final mixtures. The alkali-silica reactivity was investigated in compliance with [14], in order to evaluate the possible decay of mud bricks (in terms of cracks).

Each testing method is defined by [11] and refers to specific technical standards.

\subsubsection{Chemical properties}

The chemical characterisation of mud was carried out according to [11]. Water-soluble constituents, water-soluble chloride, water-soluble and acid-soluble sulphate, total sulphur, presence of humus and lightweight contaminants were the main properties investigated. Moreover, the organic contaminant content was determined (in compliance with [15]), in order to verify the presence of organic matter able to influence mechanical performances of mud bricks. Mortar samples of 40 × 40 × $160 \mathrm{~mm}$ with non-treated and pre-treated (by an incineration process at $480^{\circ} \mathrm{C}$ for 4 hours) mud samples were designed and tested to measure initial setting time and compressive strength.

Regarding the environmental suitability of mud samples, oxides content, chemical composition and release of pollutants tests were carried out. The X-Ray Diffraction analysis (XRD) was applied to determine the content of oxides, in compliance with [16]. The 
leaching test was carried out according to [17] based on contaminants extraction in a single stage in demineralised water (liquid/solid ratio, $\mathrm{L} / \mathrm{S}=10$ ) for a period of $24 \mathrm{~h} \mathrm{[3]}$.

\subsection{Mud bricks production and characterisation}

Several mixtures based on waste mud (dried at $105^{\circ} \mathrm{C}$ for 3 hours), binder, lightening and fibre (saturated with water in order to hinder its absorption during the mixture realisation) were produced and tested to identify a final product with mechanical properties suitable for the intended use. Table 1 lists all the mixtures performed.

Table 1. Mixtures performed for the mud brick production.

\begin{tabular}{|c|c|c|c|}
\hline Mixture & Binder $(\mathrm{w} / \mathrm{w})$ & Lightening $(\mathrm{v} / \mathrm{v})$ & Fibre $(\mathrm{v} / \mathrm{v})$ \\
\hline RM & - & - & - \\
\hline RM-L6 & L 6\% & - & - \\
\hline RM-L5-G5 & $\mathrm{L} 5 \%+5 \% \mathrm{G}$ & - & - \\
\hline RM-C6 & C $6 \%$ & - & - \\
\hline RM-L6-RH1:1 & L 6\% & - & RH 1:1 \\
\hline RM-L6-EV1:1 & L 6\% & EV 1:1 & - \\
\hline RM-L6-SD1:1 & L 6\% & - & SD 1:1 \\
\hline RM-L6-S1:1 & L 6\% & - & S 1:1 \\
\hline RM-L6-S1:0.5 & L 6\% & - & S 1:0.5 \\
\hline RM-L10-S1:0.5 & L $10 \%$ & - & S 1:0.5 \\
\hline RM-G6-RH1:1 & G 6\% & - & RH 1:1 \\
\hline RM-G6-EV1:1 & G 6\% & EV $1: 1$ & - \\
\hline RM-G6-SD1:1 & G 6\% & - & SD $1: 1$ \\
\hline RM-C6-RH1:1 & C 6\% & - & RH $1: 1$ \\
\hline RM-C6-EV1:1 & C 6\% & EV 1:1 & - \\
\hline RM-C6-S1:1 & C $6 \%$ & - & SD 1:1 \\
\hline RM-SA1:1-S1:1 & - & S 1:1 & - \\
\hline RM-SA1:1-S1:1-EP1:0.5 & - & EP 1:0.5 & $\mathrm{S} 1: 1$ \\
\hline RM-SA1:1-S1:1-EP1:1 & - & EP $1: 1$ & S $1: 1$ \\
\hline RM-SA1:1-S1:1-SD1:1 & - & SD 1:1 & S $1: 1$ \\
\hline RM-SA1:1-L6-S1:1 & L 6\% & - & S $1: 1$ \\
\hline RM-SA1:1-L10-S1:1-EP1:1 & L $10 \%$ & EP $1: 1$ & S $1: 1$ \\
\hline RM-SA1:1-C3-S1:1 & C 3\% & - & S $1: 1$ \\
\hline RM-SA1:1-C6-S1:1 & C 6\% & - & S 1:1 \\
\hline RM-SA1:1-C6-S1:1.5 & C 6\% & - & S $1: 1.5$ \\
\hline RM-SA1:1-C10-S1:1 & C $10 \%$ & - & S 1:1 \\
\hline RM-SA1:1-C10-S1:1-EP1:1 & $\mathrm{C} 10 \%$ & EP $1: 1$ & $\mathrm{~S} 1: 1$ \\
\hline
\end{tabular}

Legend: Recycled Mud (RM), Sand (SA), Lime (L), Gypsum (G), Cement (C), Expanded Vermiculite (EV), Expanded Perlite (EP), Rice Husk (RH), Saw Dust (SD), Straw (S).

In order to increase mechanical performances, lime (L), gypsum (G) and Portland cement $42.5 \mathrm{R}(\mathrm{C})$ in different percentages were adopted as binder materials, whereas expanded vermiculite (EV) and expanded perlite (EP) were used as lightening to decrease the specific weight of mixtures. Finally, rice husk (RH), sawdust (SD) and straw (S) were adopted as fibre to increase strength, improve the lightening of the final mixtures and drain the moisture during the drying stage. Some mixtures were designed adding sand (in a weight ratio 1:1 compared to mud) in order to improve strength and geometric stability of bricks. Binders were added in different percentages relative to dried mud weight $(\mathrm{w} / \mathrm{w})$, whilst lightening and fibre relative to dried mud volume (v/v). 
Mixtures without sand where prepared in cubes of $10 \times 10 \times 10 \mathrm{~cm}$ (handmade), whilst mixtures containing sand both in cubes of $10 \times 10 \times 10 \mathrm{~cm}$ (handmade) and in bricks with 5 $\mathrm{x} 10 \mathrm{~cm}$ cross section and variable length (extruded with a machine developed specifically to produce mud bricks [18].

Moisture, specific weight and compressive strength were determined for the different mixtures, then the best performing ones were subjected to a deeper investigation focused on direct tensile strength [19] and leaching behaviour [17].

\section{Results and discussion}

\subsection{Recycled mud properties}

\subsubsection{Geometrical requirements}

The results of the grain size distribution analyses are provided in Fig. 2. The tested material was composed by $80 \%$ silt, about $10 \%$ sand and $10 \%$ clay. Significant differences in the granulometric distribution amongst S1 and S2 samples were not highlighted, whilst a greater discrepancy could be noted relative to the ideal distribution curves for rammed earth and brick production [20]. The low sand content suggested the need for a particle size correction during the production of mud bricks, in order to guarantee a higher compressive strength.

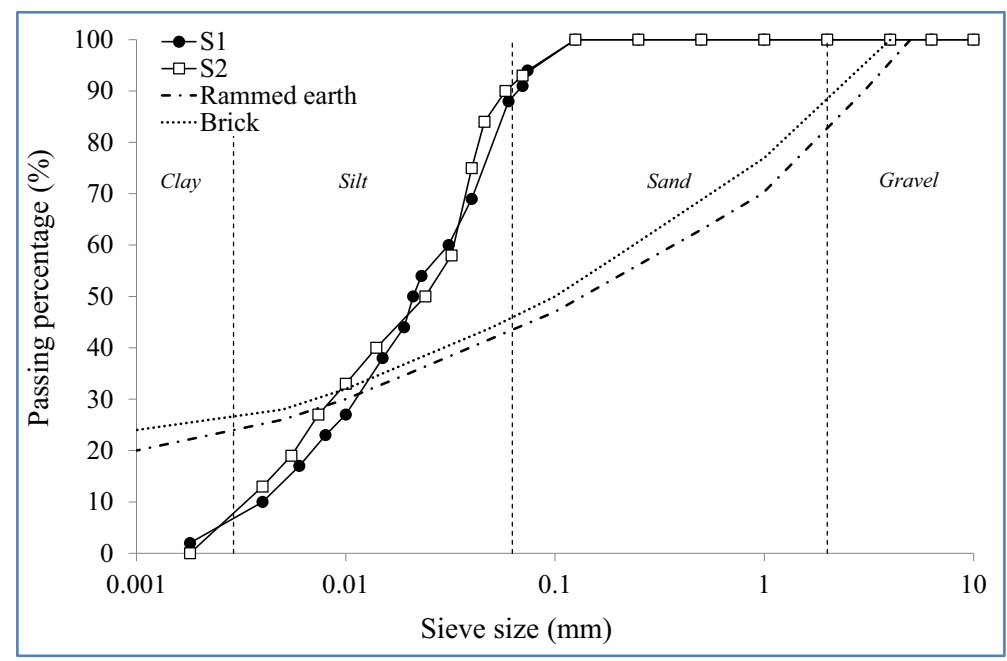

Fig. 2. Grain size distribution curves of recycled mud samples, in compliance with ASTM D 422-63, and ideal curves for rammed earth and brick production.

Test results for the assessment of fines quality (conducted on sample S1) indicated, as expected, the suitability of the material to adsorb ions or other elements in solution. Methylene blue test provided a high value of adsorption $(3.1 \mathrm{mg} / \mathrm{kg})$ considering that for the use of aggregates in concrete, the specific standard [21] fixes a value lower than 1.2 $\mathrm{mg} / \mathrm{kg}$. Sand equivalent resulted equal to $0.09 \%$ (the reference value for aggregates in concrete is set higher than $70 \%$ ), meaning that the amount of ultrafine particles represented all the material analysed, whilst the sand component was almost no measurable. 


\subsubsection{Physical requirements}

Mud particle density was measured to be $2,728 \mathrm{~kg} / \mathrm{m}^{3}$. This value seemed slightly high, but suitable if typical values of bulk density (in the range $1,600-2,100 \mathrm{~kg} / \mathrm{m}^{3}$ ) are considered. As specified in [11], an aggregate with these characteristics (particle density higher than $2,400 \mathrm{~kg} / \mathrm{m}^{3}$ ) does not provide durability problems in mortars when subjected to phenomena of freezing and thawing. Water content was evaluated according to the testing method [22] and provided a value of $12 \%$ for S1 and S2 sample. These results were comparable to the ones obtained in a previous characterisation made on samples S3 and S4, where water contents were equal to 12 and $14 \%$ respectively. Even if water content strictly depends on the compression rate set in the filter press, these values permit a suitable recovery of waste mud in unfired bricks, since they are close to the optimum water content range (between 15 and $25 \%$ ) that maximises plasticity and workability, as confirmed by [23].

Mud samples were analysed in order to determine the Atterberg limits, which provide important information on plasticity behaviour. Results indicate that waste mud samples were characterised by low plasticity (Fig. 3), thus a poor ability to permanently deform under stress conditions, and low compressibility, thus a poor attitude to volume reduction if subjected to compression. S1, S2 and S3 did not show an appropriate behaviour in terms of optimal extrusion (since they are located outside the grey reference area pointed out in Fig. 3), probably owing to the low clay fraction content. The presence of clay minerals, in fact, makes possible for particles to slide over each other due to the water retained in the interstitial spaces, thus favouring the extrusion [24].

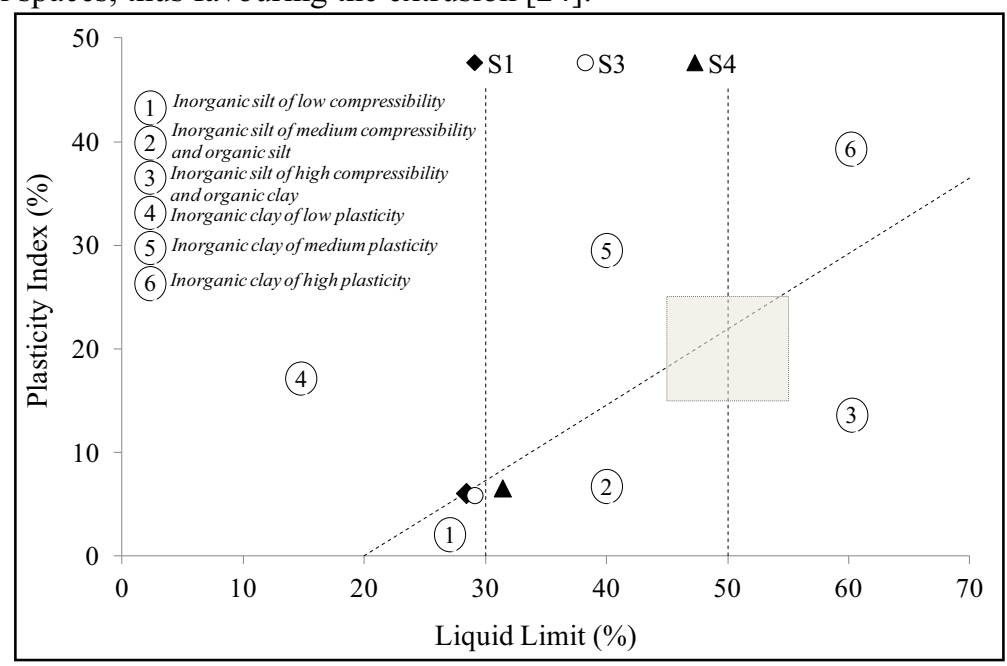

Fig. 3. Representation of mud samples in Casagrande's diagram. Grey rectangular area marks the optimal field for extrusion moulding, as highlighted in [25].

Alkali-silica reactivity was investigated in compliance with accelerated test proposed by [14]. After 14 days testing, the expansion of mud mortar samples was equal to $0.072 \%$. This value was lower than the reference limit of $0.1 \%$, thus avoiding the long-term expansion test and assuring the absence of cracking phenomena when waste mud is recovered in unfired bricks. 


\subsubsection{Chemical requirements}

The mineralogical composition of mud sample S1 was investigated through the XRD analysis. Table 2 shows that the material was mainly composed of quartz and muscovite.

High concentrations of sulphates, chlorides, barium, total chromium, arsenic and zinc were found in the chemical composition of mud samples (Table 3 ).

Table 2. Mineralogical composition of sample S1 carried out by means of XRD test [16].

\begin{tabular}{|c|c|c|}
\hline Parameter & Unit & $\mathrm{S} 1$ \\
\hline Quartz & $\%_{\mathrm{SiO}_{2}}$ & 30 \\
\hline Muscovite & $\% \mathrm{~K}_{2} \mathrm{Al}_{4}(\mathrm{Si}, \mathrm{Al})_{8} \mathrm{O}_{20}(\mathrm{OH})_{4}$ & 27 \\
\hline Plagioclase & $\% \mathrm{CaAl}_{2} \mathrm{Si}_{2} \mathrm{O}_{8}-\mathrm{NaAlSi}_{3} \mathrm{O}_{8}$ & 14 \\
\hline Dolomite & $\% \mathrm{CaMg}_{2}\left(\mathrm{CO}_{3}\right)_{2}$ & 13 \\
\hline Calcite & $\% \mathrm{CaCO}_{3}$ & 13 \\
\hline Chlorite & $\%(\mathrm{Mg}, \mathrm{Fe}, \mathrm{Al})_{6}(\mathrm{Si}, \mathrm{Al})_{4} \mathrm{O}_{10}(\mathrm{OH})_{8}$ & 3 \\
\hline
\end{tabular}

Table 3. Waste mud chemical composition and percentage of oxides content.

\begin{tabular}{|c|c|c|c|c|c|c|}
\hline \multirow{2}{*}{ Parameter } & \multirow{2}{*}{ Unit } & \multicolumn{4}{|c|}{ Waste mud sample } & \multirow{2}{*}{ Limits [2] } \\
\hline & & $\mathrm{S} 1$ & S2 & S3 & S4 & \\
\hline Sulphates & $\mathrm{mg} / \mathrm{kg}$ & 55.7 & - & - & - & - \\
\hline Chlorides & $\mathrm{mg} / \mathrm{kg}$ & 57.4 & - & - & - & - \\
\hline Antimony & $\mathrm{mg} / \mathrm{kg}$ & 5.8 & $<5.0$ & - & - & 10.0 \\
\hline Arsenic & $\mathrm{mg} / \mathrm{kg}$ & 35.6 & 18.2 & 13.9 & - & 20.0 \\
\hline Barium & $\mathrm{mg} / \mathrm{kg}$ & 237 & 237 & - & - & - \\
\hline Total chromium & $\mathrm{mg} / \mathrm{kg}$ & 16.8 & 28.4 & 5.8 & 35.2 & 20.0 \\
\hline Cobalt & $\mathrm{mg} / \mathrm{kg}$ & 7.6 & - & - & - & 150.0 \\
\hline Nickel & $\mathrm{mg} / \mathrm{kg}$ & 16.7 & - & 14.2 & 13.0 & 120.0 \\
\hline Lead & $\mathrm{mg} / \mathrm{kg}$ & 24.3 & 44.7 & 15.2 & 11.4 & 100.0 \\
\hline Copper & $\mathrm{mg} / \mathrm{kg}$ & 24.3 & 21.9 & 17.8 & 14.3 & 120.0 \\
\hline Vanadium & $\mathrm{mg} / \mathrm{kg}$ & 31.1 & $<0.5$ & 27.9 & - & 90.0 \\
\hline Zinc & $\mathrm{mg} / \mathrm{kg}$ & 128 & 279 & 88 & 50 & 150 \\
\hline Total silicon $\left(\mathrm{SiO}_{2}\right)$ & $\%$ & - & 52.3 & 40.0 & 48.0 & - \\
\hline Iron oxide $(\mathrm{FeO})$ & $\%$ & - & 2.3 & - & - & - \\
\hline Calcium oxide $(\mathrm{CaO})$ & $\%$ & - & $<1.0$ & - & - & - \\
\hline Aluminium oxide $\left(\mathrm{Al}_{2} \mathrm{O}_{3}\right)$ & $\%$ & - & 2.7 & - & - & - \\
\hline Magnesium oxide $(\mathrm{MgO})$ & $\%$ & - & 5.9 & - & - & - \\
\hline Manganese oxide (MnO) & $\%$ & - & 0.1 & - & - & - \\
\hline
\end{tabular}

Note: in all the samples tested, the following pollutants had concentrations under the detection limit: F-, CN-, Be, $\mathrm{Cd}, \mathrm{Cr}$ VI, $\mathrm{Hg}, \mathrm{Tl}, \mathrm{Se}, \mathrm{Sn}, \mathrm{C}<12, \mathrm{C}>12$, asbestos.

Regarding the latter three contaminants, in particular S1, S2 and S4 samples provided concentrations above the limit set by [3] that states a list of pollutant concentration limits above which a soil in a green residential, public and private area needs to be reclaimed. This means that these mud samples are not suitable for reuse in soil with this type of use. A slightly high variability in arsenic, total chromium, lead, vanadium and zinc content was highlighted amongst samples. This was probably due to the variability of the raw material fed and treated in the plant (construction and demolition waste, excavated soil and quarried aggregate). 
The content of oxides characterising the inert materials was also evaluated (Table 3). S2 sample was characterised by a higher content of total silicon, as compared to sample S1 (analysed by means of XRD test). The comparison between values obtained in this study and results from other researches, where dredged sediments or sludge from aggregate washing plant were analysed [25, 5, 7], highlighted the same content of total silicon (average value of 55\%), a lower content of aluminium oxide (average value of $13 \%$ ) and a higher content of magnesium oxide (average value of $1.5 \%$ ).

Chemical properties were determined $[11,13]$. Table 4 provides the results of each parameter investigated and the related more restrictive limits (since different limits are proposed by the standards, in function of the different final destinations which the use of the mortar can be addressed to).

Table 4. Chemical properties of waste mud samples, in compliance with [15].

\begin{tabular}{|l|c|c|c|c|}
\hline Parameter & Unit & S1 & S2 & $\begin{array}{c}\text { Limits of } \\
\text { UNI EN 13139 and } \\
\text { UNI 11320 }\end{array}$ \\
\hline Water-soluble constituents & $\%$ & 0.10 & 0.12 & $<1.00$ \\
\hline Water-soluble chloride & $\%$ & $<0.01$ & $<0.01$ & $<0.06^{\mathrm{a}}$ \\
\hline Water-soluble sulphate & $\%$ & $<0.01$ & $<0.01$ & - \\
\hline Acid-soluble sulphate & $\%$ & $<0.01$ & $<0.01$ & $<0.20^{\mathrm{a}}$ \\
\hline Total sulphur & $\%$ & 0.03 & 0.07 & $<0.10^{\mathrm{a}}$ \\
\hline Presence of humus & - & Colourless & Colourless & Colourless \\
\hline Lightweight contaminants & $\%$ & 0.02 & 0.03 & $<0.25^{\mathrm{a}}$ \\
\hline
\end{tabular}

Acid-soluble and water-soluble sulphate content, water-soluble chloride content, watersoluble constituents and lightweight contaminants were in compliance with the reference limits and, in some cases, even under the detection limit for both samples. Total sulphur content test provided values below the limit, even if S2 sample $(0.07 \%)$ was quite close to the reference limit $(0.10 \%)$. Presence of humus was also detected, in order to verify if organic matter can influence the mechanical behaviour of mud when recovered in unfired bricks. The analysis carried out on samples S1 and S2 provided negative results, thus avoiding to further look for organic matter by means of fulvo acid content test, as specified by the reference standards.

Mortar samples produced with Portland cement (CEM I) and untreated or pre-treated (by an incineration process at $480^{\circ} \mathrm{C}$ for 4 hours) $\mathrm{S} 1$ specimen were analysed after 28 days of curing, in order to evaluate the possible influence of organic contaminants on compressive strength and initial setting time. This latter property was not evaluated owing to the low plasticity of silt that did not permit to correctly carry out the test. Compressive strength resulted to be equal to $16.0 \mathrm{MPa}$ and 17.3 $\mathrm{MPa}$ for mortar samples, respectively made by using untreated and pre-treated waste mud, thus strengthening the slight influence of organic matter on mortar mechanical resistance.

Table 5 summarises results of leaching tests carried out in this research (samples S1 and S2) and in the previous characterisations of mud (samples S3 and S4).

Table 5. Concentrations of the pollutants in the leachate, obtained in compliance with [17].

\begin{tabular}{|c|c|c|c|c|c|c|}
\hline \multirow{2}{*}{ Parameter } & \multirow{2}{*}{ Unit } & \multicolumn{4}{|c|}{ Waste mud sample } & \multirow{2}{*}{ Limits [3] } \\
\hline & & S1 & S2 & $\mathrm{S} 3$ & S4 & \\
\hline Fluorides & $\mathrm{mg} / \mathrm{L}$ & 0.22 & 0.31 & 0.14 & 0.24 & 1.50 \\
\hline Sulphates & $\mathrm{mg} / \mathrm{L}$ & 4.88 & 4.58 & 4.65 & 3.48 & 250.00 \\
\hline Chlorides & $\mathrm{mg} / \mathrm{L}$ & 3.64 & 4.47 & 2.41 & 1.86 & 100.00 \\
\hline
\end{tabular}




\begin{tabular}{|l|c|c|c|c|c|c|}
\hline Arsenic & $\mu \mathrm{g} / \mathrm{L}$ & $<5$ & $<1$ & 35 & $<5$ & 50 \\
\hline Barium & $\mathrm{mg} / \mathrm{L}$ & 0.01 & 0.01 & $<0.02$ & 0.06 & 1.00 \\
\hline Beryllium & $\mu \mathrm{g} / \mathrm{L}$ & $<5.00$ & $<5.00$ & 6.55 & $<5.00$ & 10.00 \\
\hline $\mathrm{C}>12$ & $\mathrm{mg} / \mathrm{L}$ & - & $<0.1$ & - & - & - \\
\hline $\mathrm{C}<12$ & $\mathrm{mg} / \mathrm{L}$ & - & $<0.1$ & - & - & - \\
\hline PAHs & $\mathrm{mg} / \mathrm{L}$ & - & $<0.05$ & - & - & - \\
\hline DOC & $\mathrm{mg} / \mathrm{L}$ & 17.2 & 23.1 & 12.9 & 3.2 & 30.0 \\
\hline pH & - & 6.5 & 7.4 & - & - & $5.5-12.0$ \\
\hline
\end{tabular}

Note: in all the samples tested, the following pollutants had concentrations under the detection limit: $\mathrm{NO}_{3}^{-}, \mathrm{CN}^{-}$, $\mathrm{Cd}, \mathrm{Co}, \mathrm{Cr}, \mathrm{Hg}, \mathrm{Ni}, \mathrm{Pb}, \mathrm{Cu}, \mathrm{Se}, \mathrm{V}, \mathrm{Zn}$, asbestos.

All the parameters analysed provided concentrations below the limits indicated by [2]. A quite significant variability (from a minimum value of 3.2 to a maximum of $23.1 \mathrm{mg} / \mathrm{L}$ ) was observed for the release of DOC, comparing the results obtained in this and in the previous experimental campaign. In S2 sample, the release of Polycyclic Aromatic Hydrocarbons (PAHs) and heavy $(\mathrm{C}>12)$ and light $(\mathrm{C}<12)$ hydrocarbons was also investigated even if not required by [2]. The aim of these additional analyses was to verify the release of substances potentially present in excavated soils or construction and demolition waste treated inside the plant.

\subsection{Unfired bricks performances}

\subsubsection{Mechanical strength}

The production of brick characterised by different mix-design aimed at providing the best mechanical performances and the most eco-friendly product. The objective of the research was to define a mix-design with the higher compressive strength (in the range 1-2 MPa) accompanied by a low weight (specific weight from 1200 to $1500 \mathrm{~kg} / \mathrm{m}^{3}$ ).

The first mixture was composed only of waste mud. Then, mud brick composition was varied each time using different amounts and types of binder, lightening and fibre. The inadequacy of the waste mud particle size distribution required a correction of the mixtures with the addition of sand, in order to improve mud brick geometrical stability, reduce shrinkage and increase compressive strength. Table 6 shows results concerning physicalmechanical properties of different mud brick mixtures.

Mixtures prepared only with recycled mud and binder (RM, RM-L6, RM-L5-G5, RMC6) demonstrated interesting compressive strength values (from a minimum of 0.95 to a maximum of $4.16 \mathrm{MPa}$ ), but related to high specific weight (from a minimum of 1570 to a maximum of $1710 \mathrm{~kg} / \mathrm{m}^{3}$ ).

For this reason, lightening and fibre were added in order to decrease final density, even if these elements brought to decrease mechanical resistance under the $1 \mathrm{MPa}$ originally set as research goal. Amongst this second mixture category, indeed, only RM-C6-EV1:1 provided suitable results regarding both specific weight $\left(1.42 \mathrm{~kg} / \mathrm{dm}^{3}\right)$ and compressive strength (1.76 MPa).

Table 6. Values of moisture, specific weight and compressive strength for the different mixtures.

\begin{tabular}{|c|c|c|c|}
\hline Mixture & $\begin{array}{c}\text { Moisture } \\
(\%)\end{array}$ & $\begin{array}{c}\text { Specific weight } \\
\left(\mathrm{kg} / \mathrm{dm}^{3}\right)\end{array}$ & $\begin{array}{c}\text { Compressive strength } \\
(\mathrm{MPa})\end{array}$ \\
\hline RM & 29.6 & 1.71 & 1.61 \\
\hline RM-L6 & 44.1 & 1.65 & 1.57 \\
\hline RM-L5-G5 & 34.6 & 1.57 & 0.95 \\
\hline RM-C6 & 35.3 & 1.71 & 4.16 \\
\hline
\end{tabular}




\begin{tabular}{|c|c|c|c|}
\hline RM-L6-RH1:1 & 67.5 & 1.11 & 0.40 \\
\hline RM-L6-EV1:1 & 89.9 & 0.97 & 0.24 \\
\hline RM-L6-SD1:1 & 60.4 & 1.41 & 0.67 \\
\hline RM-L6-S1:1 & 58.9 & 1.17 & 0.48 \\
\hline RM-L6-S1:0.5 & 50.4 & 1.33 & 0.55 \\
\hline RM-L10-S1:0.5 & 54.6 & 1.34 & 0.79 \\
\hline RM-G6-RH1:1 & 50.6 & 1.51 & 0.56 \\
\hline RM-G6-EV1:1 & 55.6 & 1.33 & 0.69 \\
\hline RM-G6-SD1:1 & 56.9 & 1.64 & 0.71 \\
\hline RM-C6-RH1:1 & 56.5 & 1.41 & 0.42 \\
\hline RM-C6-EV1:1 & 52.4 & 1.42 & 0.87 \\
\hline RM-C6-S1:1 & 57.0 & 1.47 & $0.48(\mathrm{CU})-2.08(\mathrm{BR})$ \\
\hline RM-SA1:1-S1:1 & 25.4 & $1.50(\mathrm{CU})-1.58(\mathrm{BR})$ & $0.57(\mathrm{CU})-2.17(\mathrm{BR})$ \\
\hline RM-SA1:1-S1:1-EP1:0.5 & 44.0 & $1.44(\mathrm{CU})-1.32(\mathrm{BR})$ & $0.47(\mathrm{CU})-1.45(\mathrm{BR})$ \\
\hline RM-SA1:1-S1:1-EP1:1 & n.a. & $1.38(\mathrm{CU})-1.22(\mathrm{BR})$ & $0.80(\mathrm{CU})-2.06(\mathrm{BR})$ \\
\hline RM-SA1:1-S1:1-SD1:1 & 41.0 & $1.37(\mathrm{CU})-1.33(\mathrm{BR})$ & $0.67(\mathrm{CU})-1.47(\mathrm{BR})$ \\
\hline RM-SA1:1-L6-S1:1 & 49.0 & $1.42(\mathrm{CU})-1.37(\mathrm{BR})$ & $0.82(\mathrm{CU})-1.29(\mathrm{BR})$ \\
\hline RM-SA1:1-L10-S1:1-EP1:1 & n.a. & $1.35(\mathrm{CU})-1.32(\mathrm{BR})$ & $0.43(\mathrm{CU})$ \\
\hline RM-SA1:1-C3-S1:1 & 29.0 & $1.50(\mathrm{CU})$ & $1.01(\mathrm{CU})$ \\
\hline RM-SA1:1-C6-S1:1 & n.a. & $1.52(\mathrm{CU})$ & $0.99(\mathrm{CU})$ \\
\hline RM-SA1:1-C6-S1:1.5 & 40.0 & $1.48(\mathrm{CU})$ & $1.81(\mathrm{CU})-3.86(\mathrm{BR})$ \\
\hline RM-SA1:1-C10-S1:1 & 49.0 & $1.51(\mathrm{CU})-1.43(\mathrm{BR})$ & $1.85(\mathrm{CU})$ \\
\hline RM-SA1:1-C10-S1:1-EP1:1 & n.a. & $1.50(\mathrm{CU})$ & $\mathrm{C}$ \\
\hline
\end{tabular}

Legend: Recycled Mud (RM), Sand (SA), Lime (L), Cement (C), Gypsum (G), Rice Husk (RH), SawDust (SD), Straw (S), Expanded Vermiculite (EV), Expanded Perlite (EP), Cubes (CU), Bricks (BR), data not available (n.a.).

The addition of sand was the key element in order to gain the performance objectives. Moreover, the production of both cubes and bricks highlighted that the latter ones had better properties in terms of compressive strength and specific weight, as expected, due to a favourable aspect ratio and to the production via mechanical extrusion. Comparing same mixtures, in fact, extruded bricks showed a higher compressive resistance (up to about 4) with respect to handmade cubes, owing to the lower slenderness and to the reduction of eigenstresses during curing.

Adding a more eco-friendly binder as lime, mechanical properties of mixtures did not significantly vary. Longer curing in wet (or with high relative humidity) environment of specimen containing lime should however be considered to obtain adequate performances in terms of compressive strength.

Finally, the dosage of cement clearly increased the compressive resistance (on average equal to $1.42 \mathrm{MPa}$ for cubes compared to the previous $0.61 \mathrm{MPa}$ for mixtures without cement), as expected, but with a subsequent increase of specific weight (from an average value of $1.42 \mathrm{~kg} / \mathrm{dm}^{3}$ of previous mixtures to $1.50 \mathrm{~kg} / \mathrm{dm}^{3}$ of the latter ones containing cement).

Three out of all the mixtures tested were then considered for a deeper investigation. Table 7 shows the composition of mud bricks specifically produced for further analyses. 
Table 7. Composition of mud bricks produced for deeper characterisation.

\begin{tabular}{|c|c|c|c|c|}
\hline Mud brick & Silt and sand (g) & Straw (g) & Water (g) & Cement (g) \\
\hline A (stabilised) & 7,800 & 224 & 1,800 & 0 \\
\hline B1 (non-stabilised) & 8,000 & 226 & 2,300 & 400 \\
\hline B2 (non-stabilised) & 8,000 & 227 & 2,500 & 800 \\
\hline
\end{tabular}

Mixture A was not stabilised with any binder, whereas mixtures B1 and B2 were stabilised with cement in percentages of 5 and $10 \%$ respectively. All of these three new mixtures were designed in bricks of $40 \times 40 \times 160 \mathrm{~mm}$ side, according to the requirements set by [19]. Table 8 exhibits the obtained results, indicating that the three proposed mixtures might be considered a good basis for the realisation of non-structural masonry elements.

Table 8. Mechanical properties of the three new mixtures.

\begin{tabular}{|c|c|c|c|}
\hline Mud brick & $\begin{array}{c}\text { Specific weight } \\
\left(\mathrm{kg} / \mathrm{dm}^{3}\right)\end{array}$ & $\begin{array}{c}\text { Compressive strength } \\
(\mathrm{MPa})\end{array}$ & $\begin{array}{c}\text { Direct tensile strength } \\
(\mathrm{MPa})\end{array}$ \\
\hline $\mathrm{A}$ & 1.65 & 1.20 & 0.31 \\
\hline $\mathrm{B} 1$ & 1.62 & 1.36 & 0.57 \\
\hline $\mathrm{B} 2$ & 1.63 & 1.54 & 1.03 \\
\hline
\end{tabular}

The non-stabilised mud brick, owing to the lower values of compressive and tensile strength, can be used for specific architectural solutions (if subject to limited stress), in combination, for example, with load bearing timber structures. In addition, it can be useful as hygrometric stabiliser in environments exposed to significant moisture variations and as soundproofing element. Conversely, stabilised solutions can be used for the same purposes mentioned above, but even for outdoors and structural elements subjected to higher loads.

\subsubsection{Environmental suitability}

Stabilised (B2) and non-stabilised (A) mud brick samples were analysed by means of leaching test, in order to verify the environmental suitability.

The release of pollutants from the experimental bricks [17] was below the limits [3] for almost all samples (Table 9). Unexpected concentrations above the limits were provided by copper ( 0.09 with a limit of $0.05 \mathrm{mg} / \mathrm{L})$, nickel (66 and 17, respectively for stabilised and non-stabilised mud bricks, with a limit of $10 \mu \mathrm{g} / \mathrm{L})$, total chromium (71 with a limit of 50 $\mu \mathrm{g} / \mathrm{L}$ ) and DOC (156 and 65, respectively for B2 and A mud brick specimens, with a limit of $30 \mathrm{mg} / \mathrm{L}$ ). Since waste mud samples did not provide releases of those pollutants higher than the reference limits (as reported in Table 5), the exceedance of the maximum concentrations allowed [2] was probably due to the materials mixed to the recycled mud for unfired brick production. In particular, the high concentration of DOC can be traced back to straw, whilst metals to cement. Nevertheless, limits set by the Italian legislation are referred to aggregates (i.e. waste mud) and not to final products (i.e. unfired bricks). 
Table 9. Major concentrations of the pollutants released through the leaching test, in compliance with

\begin{tabular}{|c|c|c|c|c|}
\hline \multirow{2}{*}{ Parameter } & \multirow{2}{*}{ Unit } & \multicolumn{2}{|c|}{ Mud brick } & \multirow{2}{*}{ Limits [3] } \\
\cline { 3 - 4 } & & $\mathrm{A}$ & $\mathrm{B} 2$ & \\
\hline Fluorides & $\mathrm{mg} / \mathrm{L}$ & $<0.2$ & 0.9 & 1.5 \\
\hline Sulphates & $\mathrm{mg} / \mathrm{L}$ & 15.7 & 31.1 & 250.0 \\
\hline Chlorides & $\mathrm{mg} / \mathrm{L}$ & 8.9 & 15.3 & 100.0 \\
\hline Cyanide & $\mu \mathrm{g} / \mathrm{L}$ & $<0.02$ & 7.90 & 50.00 \\
\hline Arsenic & $\mu \mathrm{g} / \mathrm{L}$ & 14.8 & $<5.0$ & 50.0 \\
\hline Barium & $\mathrm{mg} / \mathrm{L}$ & 0.07 & 0.10 & 1.00 \\
\hline Copper & $\mathrm{mg} / \mathrm{L}$ & 0.02 & 0.09 & 0.05 \\
\hline Zink & $\mathrm{mg} / \mathrm{L}$ & 0.010 & $<0.005$ & 3.000 \\
\hline Nickel & $\mu \mathrm{g} / \mathrm{L}$ & 17 & 66 & 10 \\
\hline Total chromium & $\mu \mathrm{g} / \mathrm{L}$ & $<5$ & 71 & 50 \\
\hline DOC & $\mathrm{mg} / \mathrm{L}$ & 65 & 156 & 30 \\
\hline pH & - & 8.9 & 11.5 & $5.5-12.0$ \\
\hline
\end{tabular}

Note: in all the samples tested, the following pollutants had concentrations under the detection limit: $\mathrm{NO}_{3}^{-}, \mathrm{Be}$, $\mathrm{Co}, \mathrm{V}, \mathrm{Cd}, \mathrm{Pb}, \mathrm{Se}, \mathrm{Hg}, \mathrm{C}<12, \mathrm{C}>12$, PAHs, asbestos.

\section{Concluding remarks}

The possibility of making unfired bricks using recycled mud coming from an aggregate washing plant was investigated in this study. The conclusions derived from this research are as follows:

- The geometrical characterisation of recycled mud highlighted, as expected, a lack of sand in the grain size distribution analysis. In order to guarantee higher compressive strength to mud bricks, a particle size correction adding a coarser fraction (i.e. sand) is therefore required.

- The evaluation of waste mud physical requirements provided suitable results. Mud particle density was higher than $2,400 \mathrm{~kg} / \mathrm{m} 3$, thus guaranteeing (according to EN 13139 standard) mortars durability if subjected to freeze-thaw phenomena. The determination of Atterberg limits indicated that the recycled mud was characterised by low plasticity and low compressibility. Finally, alkali-silica reactivity was not detected, thus assuring the absence of cracking phenomena in unfired bricks.

- The evaluation of chemical requirements [11] provided, for all waste mud samples and parameters investigated, values below the more restrictive limits set by the reference standard.

- Concerning chemical properties, recycled mud samples highlighted a slightly high variability in chemical composition (mostly in arsenic, total chromium, lead, vanadium and zinc content), probably due to the variability of the material treated in the aggregate washing plant and for which an accurate selection should be carried out. The leaching test provided concentrations well below the limits [3] for all the parameters.

- Unfired bricks made by using recycled mud provided remarkable compressive resistances, even if not suitable for load-bearing structural elements. For being suitable for structural elements, mud bricks should however be designed adding lime or cement.

- Non-stabilised mud bricks can be used for plastic and creative architectures, featuring natural colours and by an inherent sense of warmth. The high hygroscopic adjustment 
capacity makes mud bricks suitable for the use in areas subjected to high daily variations in moisture. Finally, they can be even employed as soundproofing elements.

- $\quad$ Stabilised (using lime or cement) mud bricks can be used for the same purposes mentioned above, but even for outdoors and structural elements subjected to higher loads. These mud bricks, however, lack in hygroscopic adjustment capacity, compared to the non-stabilised ones.

This study was conducted under the research agreement "Recovery of mud coming from quarry activities in the construction sector" between the University of Brescia and the company "Cava al Tiro srl" (Martinengo, Bergamo, Italy).

The Authors wish to thank all the "Cava al Tiro" staff and the students (J. Donneschi, V. Andreoli, F. Lodrini, C. Zenari and F. Beretta) for the collaboration in the research project.

Sabrina Sorlini planned and supervised the research activities and the paper drafting; Luca Rondi did data collection and analysis on mud characterisation, and was responsible for the paper drafting; Nicola Bettini did data collection and analysis on unfired brick characterisation; Carlo Collivignarelli and Giovanni Plizzari were responsible for the agreement between University of Brescia and "Cava al Tiro srl".

\section{References}

1. Legambiente, Rapporto Cave 2014 - I numeri, il quadro normativo, il punto sull'impatto economico e ambientale dell'attività estrattiva nel territorio italiano. Ufficio Urbanistica di Legambiente. Available at: http://www.legambiente.it/sites/default/files/docs/rapporto_cave.pdf (2014).

2. Legislative Decree $04 / 03 / 2006$ n. 152 . Norme in materia ambientale. Published on Gazzetta Ufficiale n. 88 dated 04/14/2006 - Supplemento Ordinario n. 96.

3. Ministerial Decree 04/05/2006 n.186. Regolamento recante modifiche al Decreto Ministeriale 5 Febbraio 1998 "Individuazione dei rifiuti non pericolosi sottoposti alle procedure semplificate di recupero, ai sensi degli articoli 31 e 33 del Decreto Legislativo 5 Febbraio 1997 n. 22". Published on Gazzetta Ufficiale n. 115 dated 05/19/2006.

4. H. Binici, O. Aksogan, T. Shah, Constr. Build. Mater. 19, 313-318 (2005).

5. K. Hamer, V. Karius, Waste Manage. 22, 521-530 (2002).

6. H. Liu, H. Yang, Adv. Mater. Res. 641-642, 492-495 (2013).

7. A. Mezencevova, N.N. Yeboah, S.E. Burns, L.F. Kahn, K.E. Kurtis, J. Environ. Manage. 113, 128-136 (2012).

8. G. De Los Cobos, A. Parriaux, Bull. Int. Assoc. Eng. Geol. 52, 53-58 (1995).

9. C. Lampris, R. Lupo, C.R. Cheeseman, Waste Manage. 29, 368-373 (2009).

10. D.S. Parker, G.A. Horstkotte, G.A. Carthew, J. Env. Eng. Div. ASCE 101, 985-1004 (1975).

11. UNI EN 13139. Aggregates for mortar (2003).

12. UNI 11320. Aggregates for mortar - Additional provision, for the application of EN 13139 (2009).

13. American Society for Testing and Materials, ASTM D 422-63, 2007. Standard Test Method for Particle-Size Analysis of Soils.

14. UNI 8520-22. Aggregates for use in concrete - Determination of potential reactivity of alkali in aggregates (2002).

15. UNI EN 1744-1. Tests for chemical properties of aggregates - Part 1: Chemical analysis (2010). 
16. UNI EN 13925-2. Non-destructive testing - X-ray diffraction from polycrystalline and amorphous materials - Part 2: Procedures (2003).

17. UNI EN 12457-2. Leaching: Compliance test for leaching of granular waste materials and sludges - Part 2: One stage batch test at a liquid to solid ratio of $10 \mathrm{~L} / \mathrm{kg}$ for materials with particle size below $4 \mathrm{~mm}$ (2004).

18. J.P. Temga, A. Mazzù, J.P. Nguetnkam, D. Palazzini, R. Ndjouenkeu, F. Vitali, Int. J. Sust. Eng. (2013).

19. UNI EN 1015-11. Methods of test for mortar for masonry - Part 11: Determination of flexural and compressive strength of hardened mortar (2007).

20. A. Gottfried, Quaderni del Manuale di progettazione edilizia, Hoepli, Milano (Italy), ISBN 88-203-3220-5 (2003).

21. UNI 12620. Aggregates for concrete (2013).

22. CNR UNI 10008. Aggregate natural water content (1963).

23. M. Achenza, U. Sanna, I manuali del recupero dei centri storici della Sardegna - Il manuale tematico della terra cruda. ITACA (2006). Available at http://www.sardegnadigitallibrary.it/mmt/fullsize/2009022319494200003.pdf

24. M.J. Ribeiro, J.M. Ferreira, J.A. Labrincha, Ceram. Int. 31, 515-519 (2005).

25. B. González-Corrochano, J. Alonso-Azcárate, M. Rodas, J. Environ. Manage. 90, 2801-2812 (2009). 